\title{
Inversion structures in Central Europe - Expressions and reasons, an open discussion
}

\section{F. Kocke1 ${ }^{1}$ \\ ${ }^{1}$ Eiermarkt 12 B, D-30938 Burgwedel, Germany}

Manuscript received: January 2003; accepted: November 2003
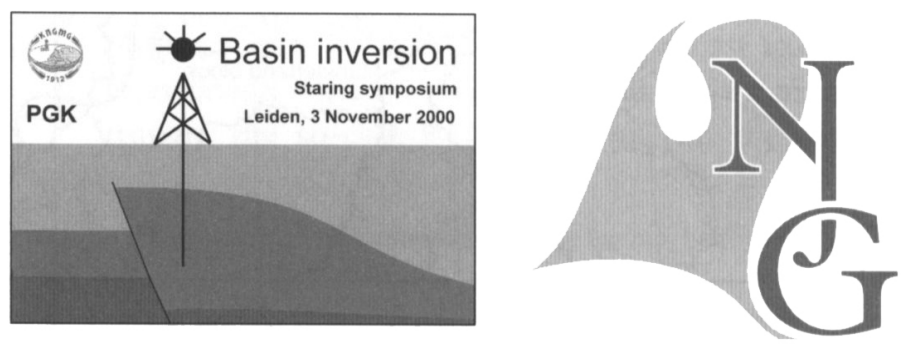

\begin{abstract}
The diversity of morphological features of Mesozoic inversion structures in NW Germany as representatives of inversion structures in northern Europe is presented and their origin analysed and geologically dated. The particular role of salt in inverted basins and the re-shaping of pre-existing salt structures during the inversion act is demonstrated and the term 'salt wedge', a Zechstein salt intrusion into salt layers within the Triassic sedimentary pile, introduced. The leading theories on inversion (continent-continent collision, re-activation Variscan features) are discussed and discarded, but no new comprehensive theory was developed. The impact of inversion on HC prospectivity of sedimentary basins is debated and proposals for future interdisciplinary research are made.
\end{abstract}

Keywords: Central Europe, inversion, NW Germany, hydrocarbon potential, salt structures

\section{Introduction}

Basin inversion is defined as the process where a reversal occurs in the sense of tectonic movement, e.g. uplift of a former depocentre and subsidence of the highs bordering the basin (Voigt, 1962a). World-wide inverted basins contain significant amounts of hydrocarbons and therefore since long these basins attracted the attention of geologists.

The intra-plate phenomenon of basin inversion has for the first time been recognised by Russian authors on the East European platform (Pripjat-Donets and other basins; Pavlov, 1887; Schatski \& Bogdanow, 1958; Schatski, 1961). In western Europe Stille (1923-1925) introduced the term of "Saxonian tectonic style" for areas like Lower Saxony which experienced earlier dilatation, followed by later compressional overprinting. Detailed descriptions of inverted basins have been given by Wolburg (1954), Schreiber
(1957), Boigk (1968), Heybroek (1974, 1975), Burke (1977) and Van Wijhe (1987). Voigt (1962a) defined an inversion structure as a former trough, basin, halfgraben or graben, which later became uplifted (aulacogene in the sense of Schatski). A comprehensive description of nearly all inverted basins in NW Europe and a first attempt to explain the phenomenon on the base of plate tectonics, has been given by Ziegler (1987b) and his co-workers. Since then a multitude of papers and summarising special publications have been published on this topic (for instance Wong et al., 1989; Baldschuhn et al., 1991; Ziegler et al., 1995, Buchanan \& Buchanan, 1995; Hooper et al., 1995; Huyghe \& Mugnier, 1995, Nalpas et al., 1995; Nalpas, 1996, Ziegler et al., 1998, Stovba \& Stephenson, 1999; Yegorova et al., 1999, Vejbaek \& Andersen, 2001). In NW Germany in the past two decades a multitude of smaller and larger inversion structures have been structurally mapped and geneti- 


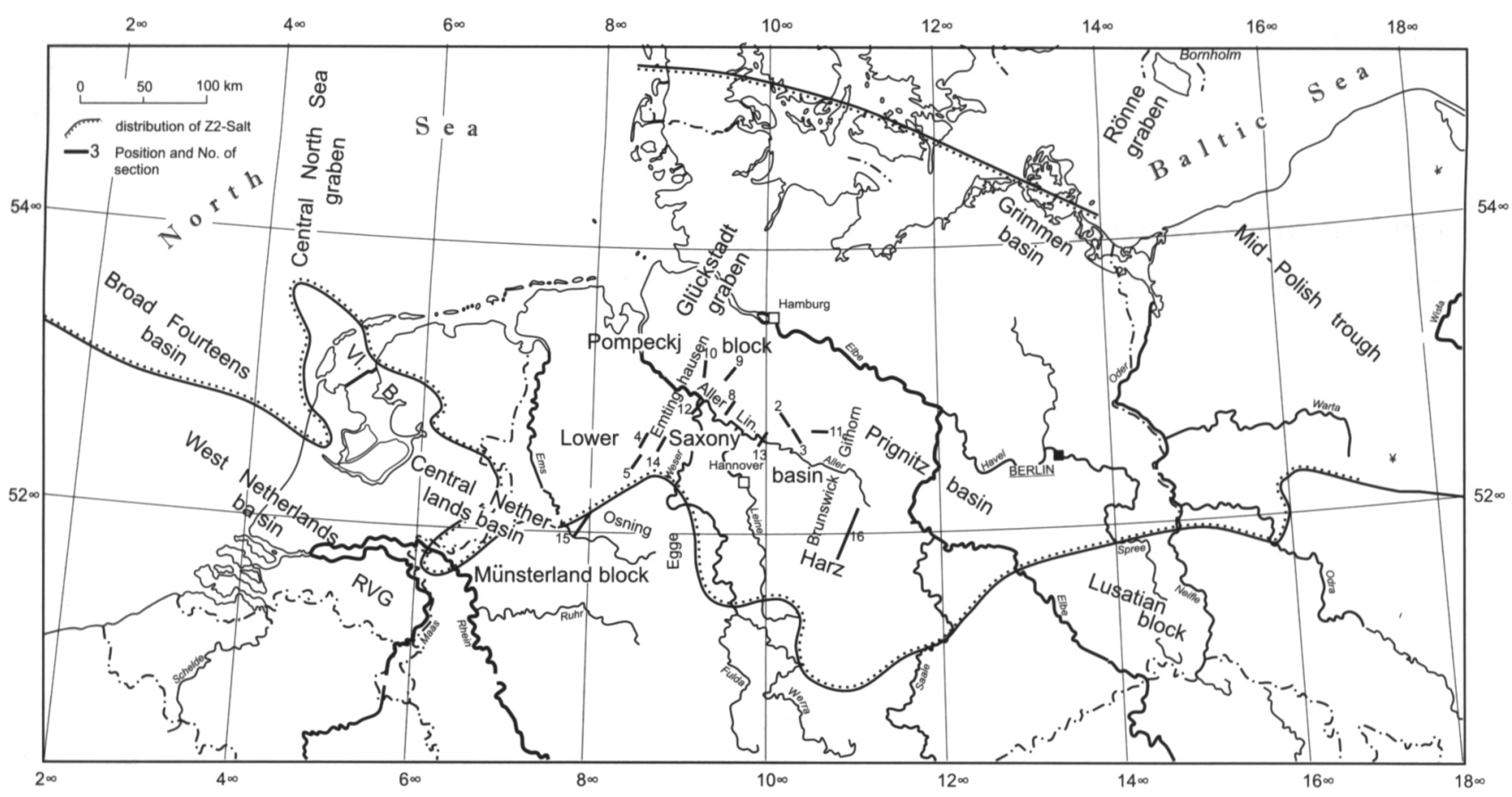

Fig. 1. Geographic positions of the sections figs. 2-13. (Vl. = Vlieland Basin, RVG = Roer Valley Graben)

cally analysed, sections, structural maps and descriptions have been published by Baldschuhn et al. (1996, 2001; Figs 2-13). These sections are based on a dense network of interpreted and depth-converted 2D-seismic lines and bore-hole data from oil companies operating in Germany as well as on surface mapping by the regional geological surveys.

The aim of this paper is to show the morphology of different types of inversion structures, analyse their genesis in time, to show the influence and role of salt in inverted basins and individual structures, to discuss various theories on the inversion process and finally to describe the impact of inversion on the hydrocarbon potential of sedimentary basins.

This study is focussed on inversion structures in NW Germany, preferably on those within the inverted Lower Saxony Basin. This basin is situated within the larger Permo-Triassic Central European Basin, which extends from eastern Poland through north Germany, the Netherlands and the southern North Sea into Britain. This uniform basin became fragmented into individual depocentres during the Jurassic and Early Cretaceous rifting and these subsequently were inverted in Late Cretaceous, some even in Tertiary times. Besides the Lower Saxony Basin the Mid-Polish Trough in Poland, the Rønne Graben off Bornholm, the Scandinavian border zone in Scania, Sweden, the Grimmen and Prignitz basin in NE Germany, the Central and West Netherlands basins, the Roer Valley Graben, the Broad Fourteens and Sole Pit basins and the Dutch Central Graben in the southern North Sea as well as many smaller graben and halfgraben structures linked to basement lineaments show comparable development of Jurassic-Early Cretaceous subsidence and Late Cretaceous inversion (Fig. 1). All these basins have been covered with dense networks of $2 \mathrm{D}$ and partly $3 \mathrm{D}$ reflection seismic and have been intensely drilled for hydrocarbons. The geological data base in these basins therefore is excellent and far better than in the classic areas of outcropping Mesozoic formations.

\section{Morphology and genesis of inversion structures}

In intra-plate inverted basins five genetic stages can be observed:

1. The formation of rapidly subsiding troughs, halfgrabens or grabens which, contemporaneously, are filled by thick and stratigraphically more complete sedimentary sequences than in the surrounding areas, the basin margins or rift shoulders. These often rise to erosion level simultaneously. Rifting activity is not a continuous process even in neighbouring structures and may start or cease at different times.

2. A period of decreasing tectonic activity, during which the differences in subsidence between the basins and the adjacent highs is compensated by filling-up of the depocentres and overstepping of sedimentation onto the flanks without ruptural deformation. This period has sometimes been named "formation of the internal sag" or "thermal sag".

3. The inversion stage, caused by shortening of the basement or crust. The filling of the former basin or graben is pressed upwards and onto the flanks or 
shoulders, anticlines with flat bottoms originate. The former normal border faults are transformed into reverse faults or thrusts or (in case the former down-throw is not compensated by the reverse activity) into "phaeno-normal faults". Contemporaneously, rapidly subsiding "subsequent marginal troughs" (Voigt, 1962a) sink into the former graben or basin shoulders, which are often filled with partly turbiditic sediments or even olisthostromes (Voigt, 1962b).

4. In a next stage non-ruptural and flexure-like uplift of the individual inversion structures or the inverted basin as a whole continues and diminishes with time.

5. In a last stage along some of the compressional reverse faults and thrusts "relaxation" movements can be observed. The reverse faults act as normal faults in opposite direction in a now again dilatational stress regime.

Inversion cycles can be very long (from Devonian to Late Cretaceous in the Pripjat-Donets Basin; Stovba \& Stephenson, 1999) or rather short-lived (from Early Jurassic to Eocene) in the Lower Saxony Basin (LSB). Also the different stages may cover different time spans (the rifting stage in the LSB lasted 116,7 $\mathrm{Ma}$, the inversion phase only ca. 11,5 Ma and the relaxation phase $53 \mathrm{Ma}$. The inverted Glückstadt Graben in Schleswig-Holstein entered its rifting phase as early as Late Rotliegend, the first true signs of inversion - the formation of a subsequent marginal trough, the so-called Hamburg pit, on the eastern

Table 1 . The timing of tectonic events in NW-Germany's inverted regions. heavy shading $=$ compressional stress regime, light shading $=$ dilatational stress regime. (Radiometric ages from Gradstein et al., 1999).

\begin{tabular}{|c|c|c|c|c|c|}
\hline $\begin{array}{l}\text { age of } \\
\text { base } \\
\text { in } \mathrm{Ma}\end{array}$ & period & $\begin{array}{l}\text { stratigraphic } \\
\text { unit }\end{array}$ & $\begin{array}{l}\text { symbol } \\
\text { in } \\
\text { section }\end{array}$ & $\begin{array}{c}\text { dura } \\
\text { tion } \\
\text { in } \mathrm{Ma}\end{array}$ & $\begin{array}{l}\text { main tectonic } \\
\text { events }\end{array}$ \\
\hline \multirow[b]{2}{*}{2,6} & \multirow{2}{*}{$\begin{array}{c}\text { Quaternary } \\
\text { (q) }\end{array}$} & Holocene & \multirow[b]{2}{*}{ (q) } & \multirow[b]{2}{*}{2,6} & \multirow{6}{*}{\begin{tabular}{|c|} 
transtensional \\
movements at selectec \\
basement \\
faults \\
"relaxation"
\end{tabular}} \\
\hline & & Pleistocene & & & \\
\hline 5,3 & \multirow{2}{*}{$\begin{array}{c}\text { Neogene } \\
\text { (tng) }\end{array}$} & Pliocene & (tpl) & 2,7 & \\
\hline 23,8 & & Miocene & (tmi) & 18,5 & \\
\hline 33,7 & \multirow{4}{*}{$\begin{array}{l}\text { Palaeogene } \\
\quad(\text { tpg })\end{array}$} & Oligocene & (tol) & 9,9 & \\
\hline 54,8 & & Eocene & (teo) & 21,1 & \\
\hline \multirow[b]{2}{*}{65} & & Late Palaeocene & (tpao) & 6,1 & \multirow{3}{*}{$\begin{array}{l}\text { upwarping } \\
\text { and erosion }\end{array}$} \\
\hline & & Danian, Montian & (td) & 4,1 & \\
\hline \multirow[b]{6}{*}{98.9} & \multirow{6}{*}{$\begin{array}{l}\text { Late } \\
\text { Cretaceous } \\
\quad(\text { kro })\end{array}$} & Maastrichtian & (krma) & 6,3 & \\
\hline & & Campanian & (krca) & 12,2 & \multirow{3}{*}{$\begin{array}{l}\text { intensive inversion, } \\
\text { thrusting, deformation } \\
\text { of salt structures }\end{array}$} \\
\hline & & Santonian & (krsa) & 2,3 & \\
\hline & & Coniacian & (krcc) & 3.2 & \\
\hline & & Turonian & (krt) & 4,5 & \multirow{4}{*}{$\begin{array}{l}\text { formation of the } \\
\text { "internal sag" without } \\
\text { fracturing }\end{array}$} \\
\hline & & Cenomanian & (krc) & 5,4 & \\
\hline \multirow[b]{6}{*}{142} & \multirow{6}{*}{$\begin{array}{l}\text { Early } \\
\text { Cretaceous } \\
\quad(k r u)\end{array}$} & Albian & $(\mathrm{krl})$ & 13,3 & \\
\hline & & Aptian & (krp) & 8,8 & \\
\hline & & Barremian & (krb) & 6,0 & \multirow{4}{*}{$\begin{array}{c}\text { intensive } \\
\text { rifting }+ \text { subsidence, } \\
\text { diapirism }\end{array}$} \\
\hline & & Hauterivian & (krh) & 5,0 & \\
\hline & & Valanginian & (krv) & 5,0 & \\
\hline & & $\begin{array}{l}\text { Berriasian } \\
\text { (Wealden) }\end{array}$ & $(\mathrm{Wd})$ & 7,2 & \\
\hline \multirow[b]{7}{*}{159,4} & \multirow{7}{*}{$\begin{array}{l}\text { Late } \\
\text { Jurassic } \\
\text { (Malm) } \\
\text { (jo) }\end{array}$} & Serpulit & (joS) & \multirow{4}{*}{6,6} & \multirow{5}{*}{$\begin{array}{c}\text { very intensive rifting }+ \\
\text { rapid subsidence } \\
\text { diapirism }\end{array}$} \\
\hline & & Münder Mergel & (joM) & & \\
\hline & & Eimbeckh. PK. & (joE) & & \\
\hline & & Gigas beds & (joG) & & \\
\hline & & "Kimmeridgian" & (joKI) & 3,4 & \\
\hline & & Korallenoolith & (joK) & \multirow[b]{2}{*}{5,3} & \multirow{10}{*}{ rifting, subsidence } \\
\hline & & Heersum bed & $(\mathrm{joH})$ & & \\
\hline \multirow[b]{4}{*}{180,1} & \multirow{4}{*}{$\begin{array}{c}\text { Middle } \\
\text { Jurassic } \\
(\mathrm{jm})\end{array}$} & Callovian & (jmcl) & 5,0 & \\
\hline & & Bathonian & (jmbt) & 4,8 & \\
\hline & & Bajocian & (jmbj) & 7,3 & \\
\hline & & Aalenian & (jmal) & 3,6 & \\
\hline \multirow[b]{4}{*}{205,7} & \multirow{4}{*}{$\begin{array}{c}\text { Early Jurassic } \\
\text { (Liassic) } \\
\text { (ju) }\end{array}$} & Toarcian & (jutc) & 9,5 & \\
\hline & & Pliensbachian & (jupl) & 5,7 & \\
\hline & & Sinemurian & (jusi) & 6,6 & \\
\hline & & Hettangian & (juhe) & 3,8 & \\
\hline
\end{tabular}


b)

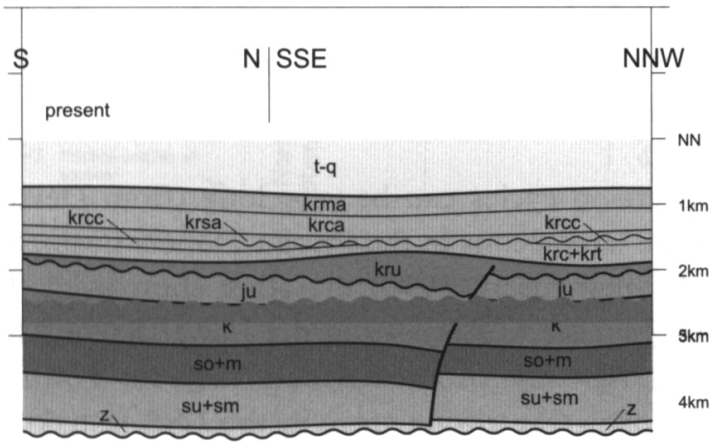

a)

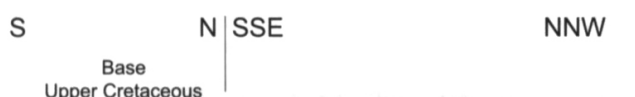

Upper Cretaceous

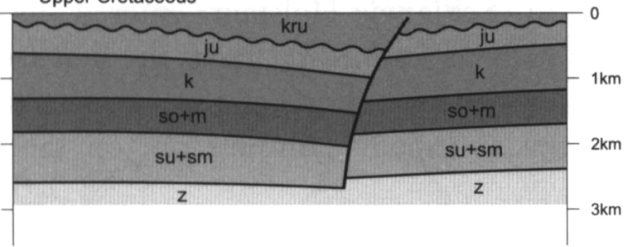

Dig. Bearb.: B. Borach

Fig. 2. Fassberg structure. Unilateral inversion structure on the Pompeckj block (PB). (a) Late Jurassic: uplift and erosion of Middle Jurassic and parts of Lower Jurassic. Early Cretaceous: formation of a half-graben with a northern boundary fault. (b) Albian to Turonian: Cessation of the graben subsidence. Coniacian to Middle Santonian: inversion of the graben, non-sedimentation and erosion of Coniacian and parts of Turonian and Cenomanian, reverse faulting along the former graben boundary fault, not compensating the former amount of down-throw ("phaeno-normal fault"). Late Middle and Late Santonian: transgression over the structural crest, further up-warping of the structure. Early Campanian to Late Tertiary: no further individual tectonic activity, feeble subsidence of the structural crest (Baldschuhn et al., 1991).

For stratigraphical symbols see table 1 . In addition: $\mathrm{k}=$ Keuper, $\mathrm{so}+\mathrm{m}=$ Upper Buntsandstein + Muschelkalk, su $+\mathrm{sm}=$ Lower and Middle Buntsandstein, $\mathrm{z}=$ Zechstein, ro $=$ Upper Rotliegend, $\mathrm{c}=$ Carboniferous.

NNE

SSW

b)

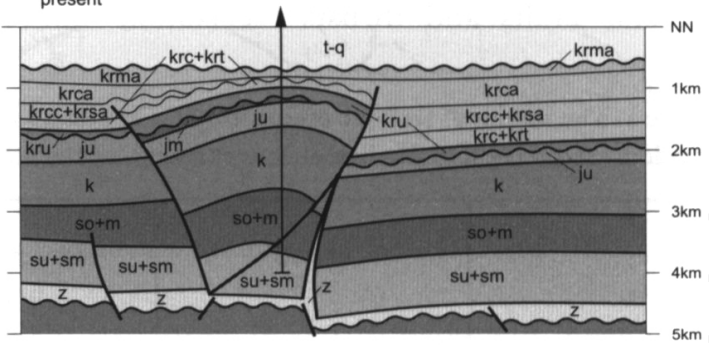

Fig. 3. Unterlüss structure. Bipolar inversion structure on the PB. (a) Late Jurassic: Subsidence of a small graben structure, which existed already in Keuper times, uplift and erosion of Middle and partly Lower Jurassic rocks, to a lesser extent in the graben than on the shoulders (Upper Toarcian preserved). Early Cretaceous: Further subsidence of the graben, bordered by two boundary faults. (b) Coniacian to Late Santonian: inversion of the graben, up-warping of the graben fill, reverse movements along the former graben boundary faults, non-deposion and erosion on the crest. Late Santonian to Campanian: transgression over the crest of the structure, thrusting and further upwarping. Maastrichtian to Miocene: end of upwarping, no further individual movements (Baldschuhn et al., 1991).

NNE

SSW

a)

Base Upper Cretaceous

)

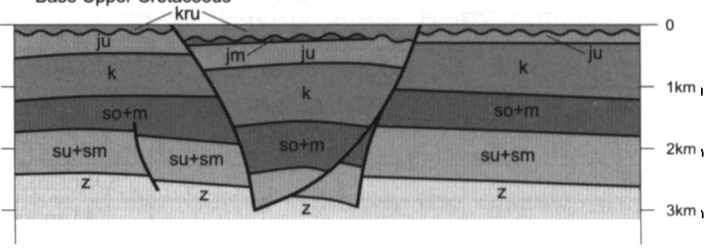

Dig. Bearb.: B. Borach

Dïste

sw

\section{Ridderade}

b)

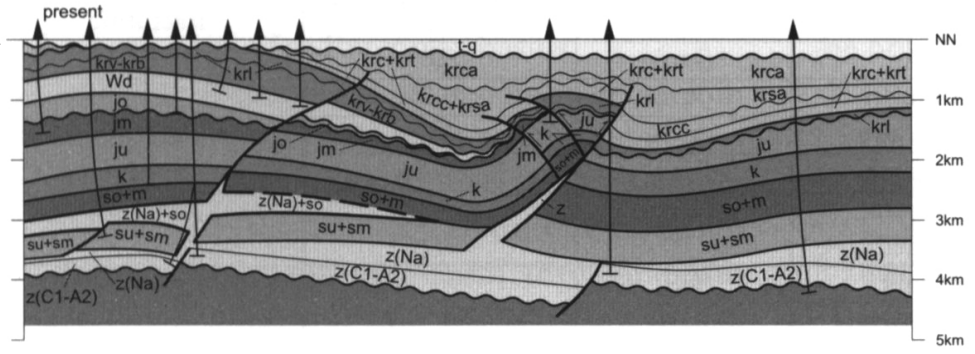

:SW

\section{Base Coniacian}

a)

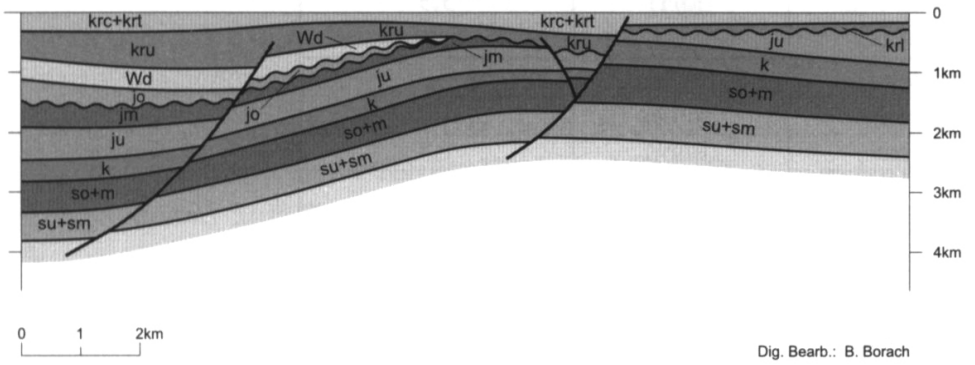

Fig. 4. Ridderade-Düste inversion structures. Two minor inversion structures at the northern margin of the Lower Saxony basin (LSB) to the PB. (a) PreConiacian: The Düste structure during the Late Jurassic and Early Cretaceous is a faulted basin north of the Donstorf High (see Fig. 5), the Ridderade structure is a narrow y-shaped graben subsiding in Early Cretaceous times and immediately straddling the block boundary fault between the LSB and the PB. (b) During Coniacian and Santonian both structures became inverted. The Düste structure became an anticline, slightly disturbed by a reverse fault along the northern flank, the Ridderade Graben was pressed up into a bipolar pop-up-structure, accompanied north and south by deep marginal troughs filled with thick Coniacian and Santonian sediments, partly with flysch character. Note the Zechstein salt intrusion within the Triassic Röt salt layer underlying the Düste structure. No individual up-buckling after the Late Palaeocene (Baldschuhn et al., 1991). 


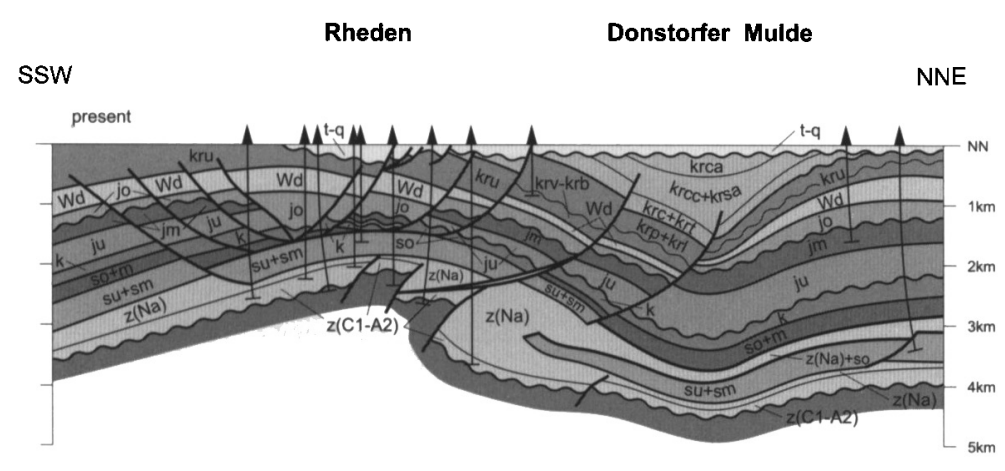

SSW

NNE

b))

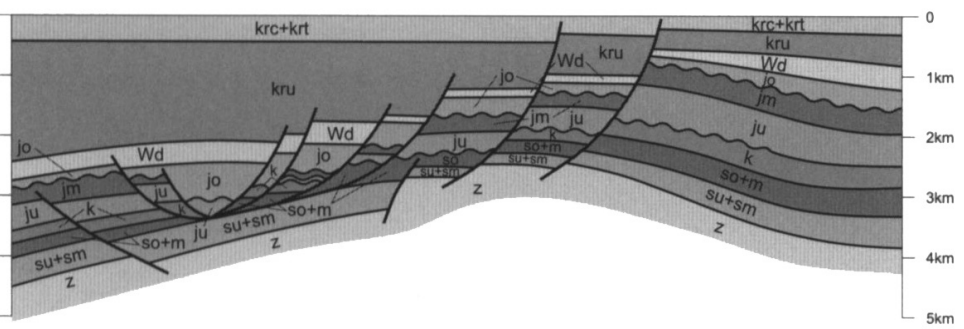

SSW

Base Upper Jurassic

NNE

a)'

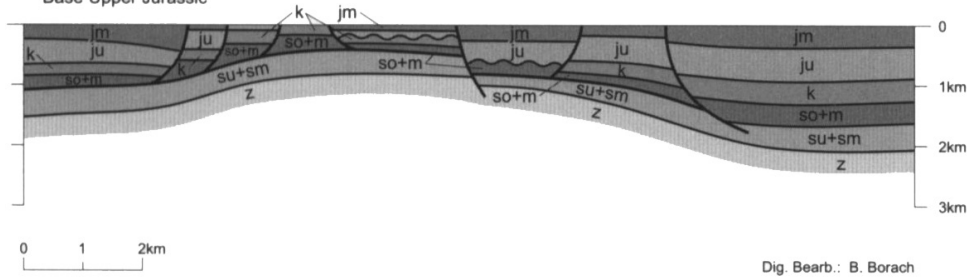

Fig. 5. Rehden inversion structure, super-imposed over a Triassic half-graben (southern continuation of the Fig. 4). (a): Middle Buntsandstein: Syngenetic fault, seperating a subsiding block in the South and a less rapidly subsiding block in the North. Keuper to Middle Jurassic: a complex horst formed and was deeply eroded before the Late Jurassic (pre-Middle Kimmeridgian) transgression. (b) Late Jurassic: on top of the former horst a small graben formed. Berriasian to Aptian: the southern part of the structure became a syn-sedimentary subsiding staircase of blocks bordering the main LSB to the north. (c) Coniacian to Campanian: during the inversion of the entire LSB the Rheden structure was individually inverted, upwarped and the former boundary faults of the step blocks reversed. The underlying Carboniferous basement was also thrusted to the North. On the former high to the north of the structure (Donstorf High), a deep subsequent marginal trough, the Donstorf trough formed, filled with thick Coniacian and Santonian sediments. The Rehden structure as integrated part of the LSB during the Tertiary was tilted towards the North and frequently eroded.

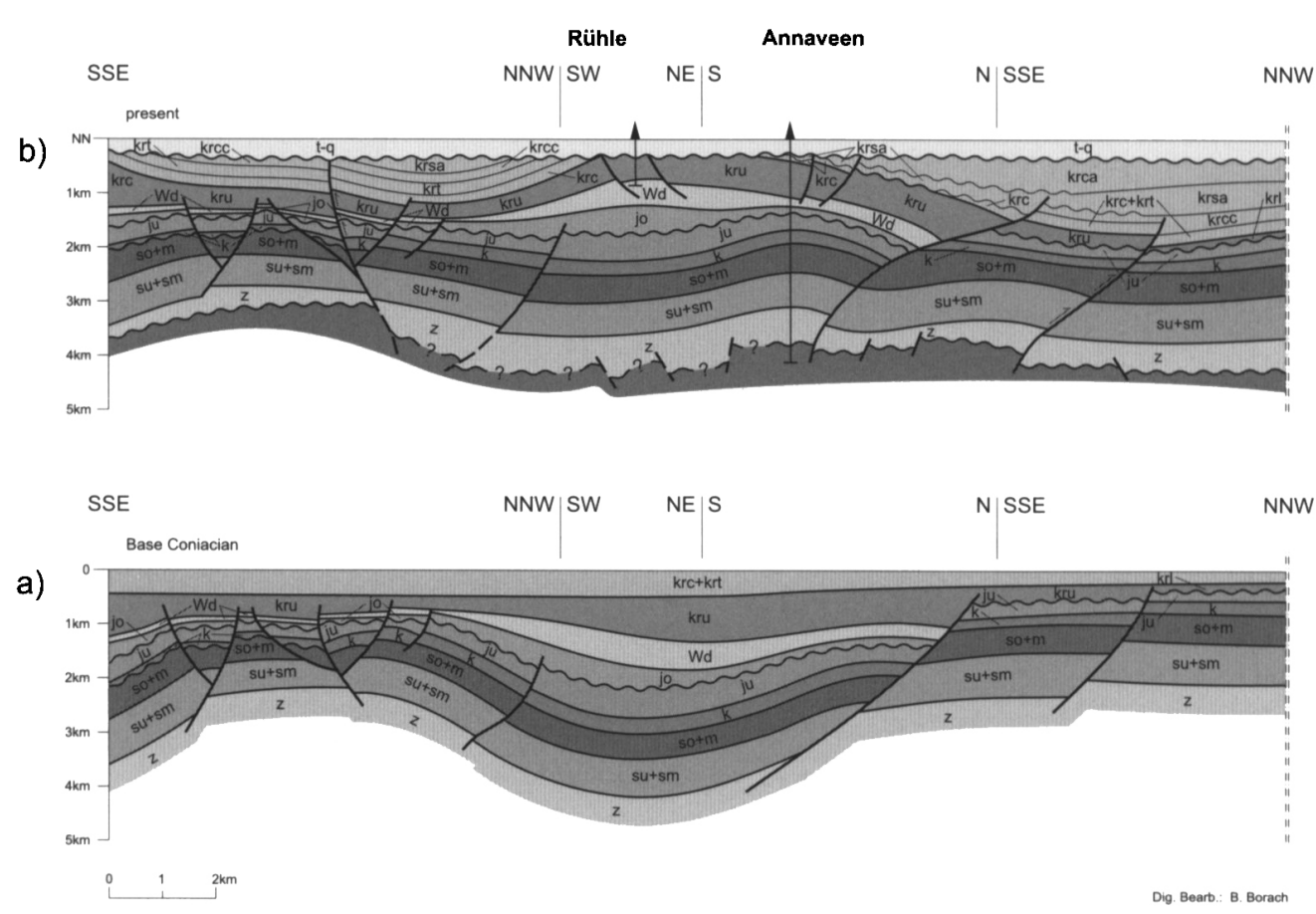

Fig. 6. Rühle-Annaveen inversion structure and Adorf inverted graben (western LSB). (a) From the Late Jurassic (Gigas beds) onwards the Rühle-Annaveen structure was a subsiding trough bordered by a syn-sedimentary fault in the North and by the Adorf ridge in the South. Note the migration of the depocentre towards the North during Late Jurassic to Early Cretaceous times. The Adorf structure was a simple ridge in Late Jurassic and Berriasian times, during the Early Cretaceous a complex crest graben formed on its top. (b) During inversion in Coniacian and Santonian times the filling of the Rühle Trough was up-warped, the structural HC-trap in the Bentheim sandstone (Valanginian) was formed, the northern boundary fault was transformed into a partly under-compensated reverse fault ("phaeno-normal fault"). The Adorf structure also was moderately inverted. Both structures did not move individually since the Palaeogene (Baldschuhn et al., 1991). 


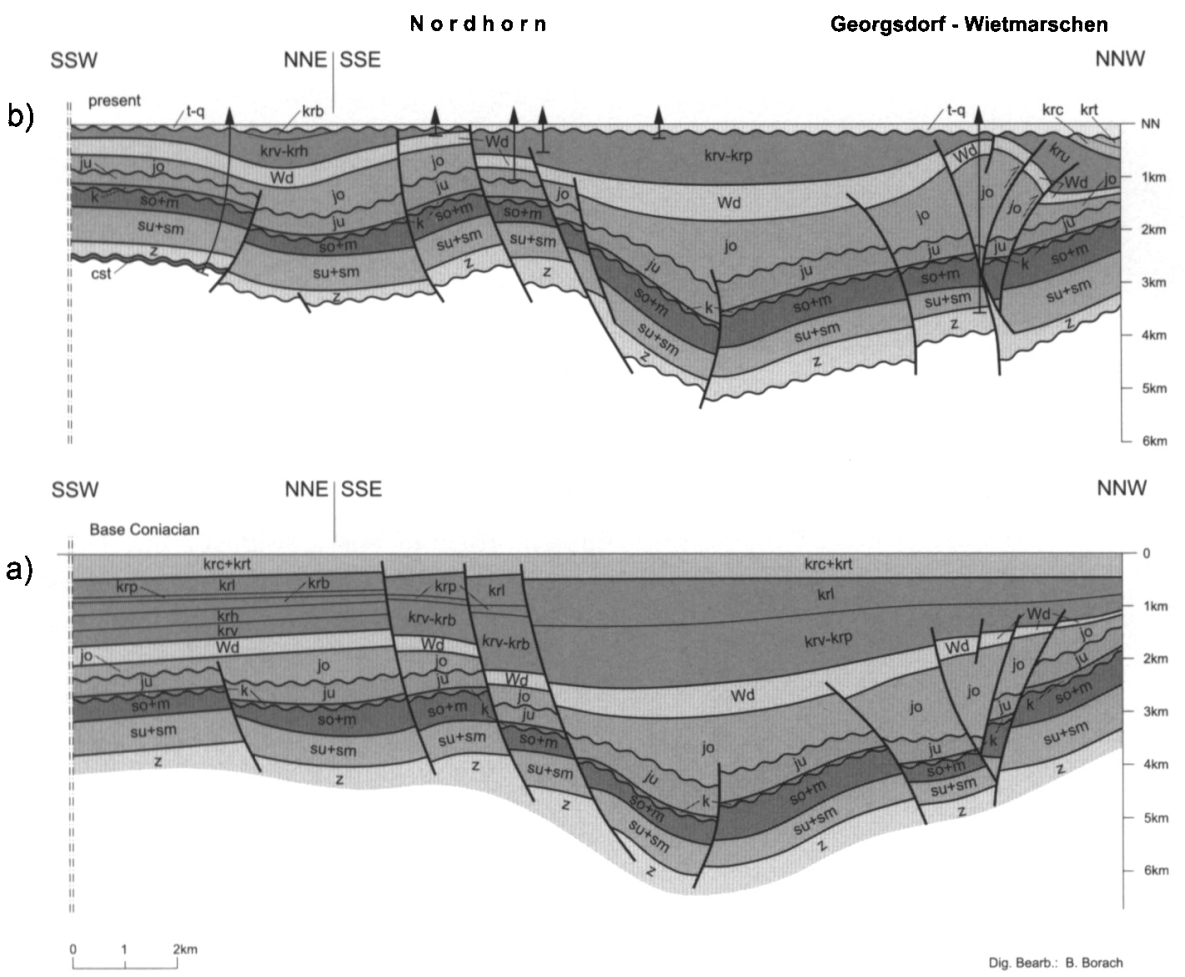

Fig. 7. Nordhorn and Georgsdorf-Wietmarschen inversion structures (prolongation of the section Fig. 6 towards the south (LSB). The Upper Jurassic Georgsdorf-Wietmarschen Graben was a syn-sedimentary graben-ingraben structure between the Nordhorn horst and the Adorf swell. During inversion it was transformed into a pop-up-structure. This inversion structure is modified by the mobilisation of the Upper Jurassic salt which additionally pressed up the roof of the structure. At the northern flank of the Nordhorn inversion structure one can observe palaeo-oil-seeps in the Bentheim sandstone forming little cliffs as it is cemented by $\mathrm{HC}$, which subcrop beneath the Eocene transgression. No individual up-buckling after the Late Palaeocene (Baldschuhn et al., 1991). shoulder of the graben - are dated as Eocene. The timing of tectonic events in NW-Germany's inverted regions is summarized in Table 1.

The Figs 2 to 7 show examples of inversion structures in the LSB and on the southern Pompeckj block and explain their genesis in time.

\section{The role of salt in inverted basins}

The great difference in structural morphology is if inverted basins contain salt or not. Parts of the inverted basins mentioned contain salt structures (salt pillows, diapirs and alike; for distribution of the Zechstein 2
Stassfurt rock salt see Fig. 1). The growth of salt structures is generally triggered by basement faulting during the dilatation phase (Triassic-Early Cretaceous and Tertiary). In NW Germany most of the diapirs straddle basement lineaments or rift boundary faults. Further rifting led to the break-up of the overburden and thus opened the salt a way to flow out to form a diapir. It is not the buoyancy effect of the salt alone that makes the overburden burst. In contrast to the theory of Stille (1917) on "ejection folding" of salt, no salt diapir has been observed to originate from compressional tectonic phases. If diapirs undergo compression during the inversion phase, the salt is

Düshorn

Hodenhagen

NW

SE

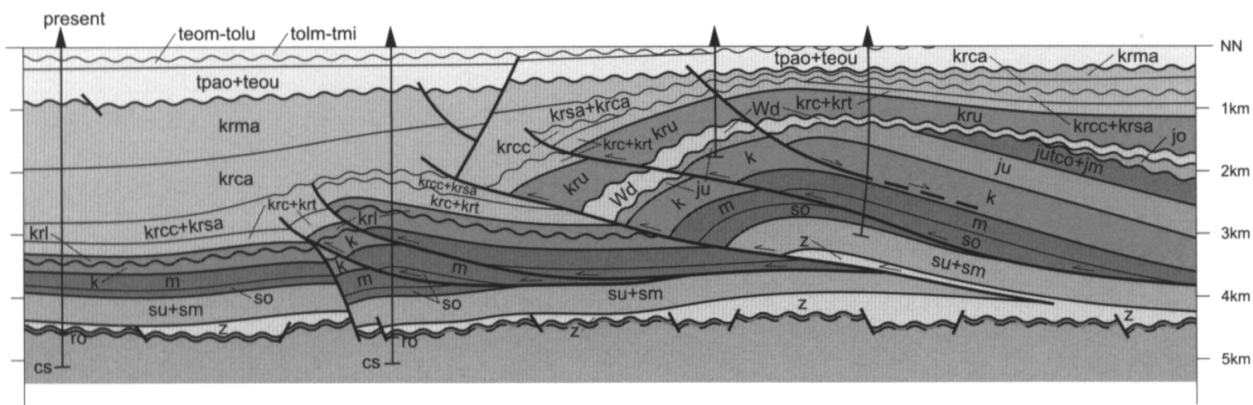

${ }_{0}^{0} \quad 1 \quad 2 \mathrm{~km}$

Dig. Bearb: B. Borach

Fig. 8. Düshorn and Hodenhagen inversion structures. Both structures straddle different basement faults of the Aller lineament, the northern boundary of the eastern LSB. The different timing of the inversion act can be read from the age of the Late Cretaceous unconformities covering the crests of the structures. While the Düshorn structure became inactive already during Early Campanian, the Hodenhagen structure still rose during the Maastrichtian. Mark the reactivation of the uppermost former thrust rooting in the Middle Keuper as a normal, SE-dipping fault in the Palaeogene. 
Fig. 9. Söhlingen salt structure (PB). The salt wedges intruding into the Upper Buntsandstein Röt salt level during the compressional inversion phase (Coniacian-Campanian). The wedges are tilted by post-Cretaceous rise of the diapir (Baldschuhn et al., 1998).

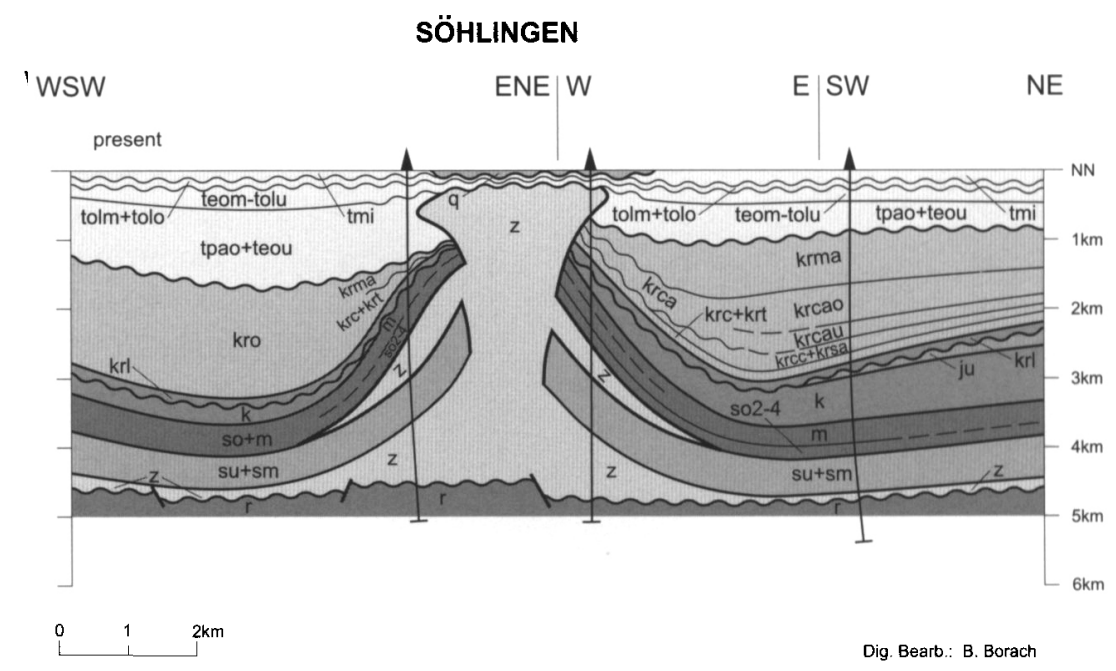

squeezed out, the stems of the salt structures become compressed and thin, and large overhangs develop, many of them probably submarine salt glaciers in the Cretaceous sea (Baldschuhn et al., 1998). Additional Permian salt may migrate in form of wedges into the neighbouring Mesozoic sequence, preferable into the salt layers of the Triassic, the Upper Buntsandstein (Röt), Middle Muschelkalk and Middle Keuper salt layers. These salt intrusions lift up the younger sedimentary pile and normally are underlain by flat lying Lower and Middle Buntsandstein. On seismic data an angle between the Buntsandstein and the Muschelka$\mathrm{lk}$ reflectors can be observed. These salt wedges, consisting of a mixture of Permian and Triassic salts have also been drilled in many places in NW Germany. The Figs 8-12 give examples of inversion-affected salt structures and salt wedges. Sandbox modelling in compressional regimes have lead to very similar pictures. (compare Fig. 12 with Fig. 11 in Koyi, 1998).

If a salt wedge later is uplifted into the ground water level, it may be entirely leached. The roof of the wedge then will collapse and areas with numerous incoherent blocks of upper Triassic rocks without any

\section{WITTINGEN}

W

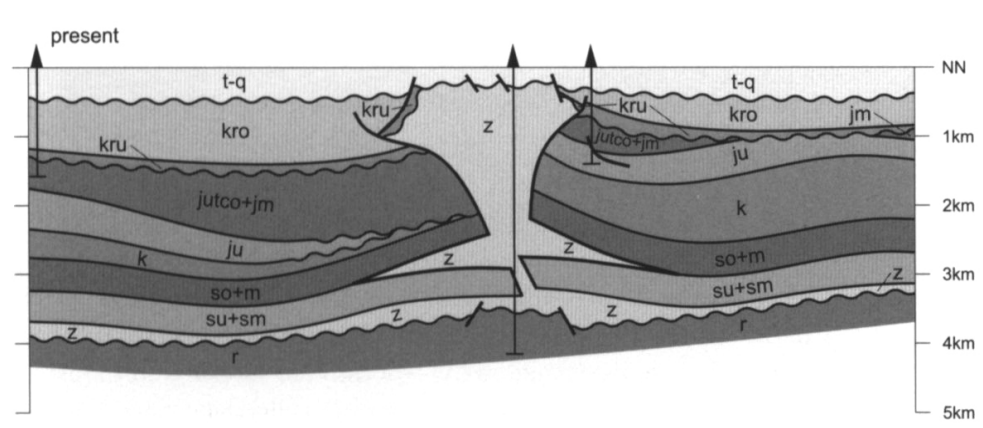

Fig. 11. Wittingen salt diapir. The salt diapir straddles the NNE-SSW-trending Braunschweig-Gifhorn fracture zone. The diapiric phase took place in the Middle Jurassic times, compressional deformation and the intrusion of Zechstein salt wedges in the Upper Buntsandstein salt level in Late Cretaceous times (Baldschuhn et al., 1998). 


\section{EITZENDORF}

S N SSW

NNE

present

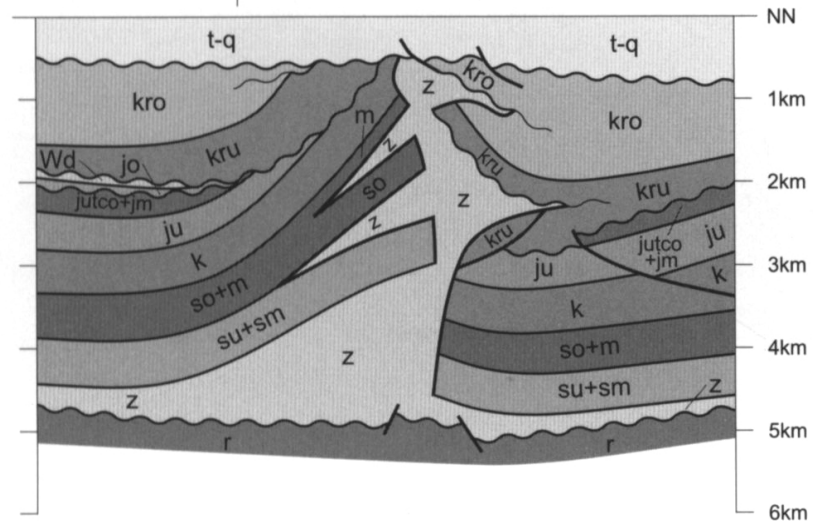

$0 \quad 12 \mathrm{~km}$

Dig. Bearb.: B. Borach

Fig. 12. Eitzendorf. The structure straddles the inverted Aller lineament (eastern LSB). The diapiric phase began in Early Cretaceous times (see secondary rim syncline in the SW). The Zechstein salt wedges intruded into the Röt and Middle Muschelkalk salt levels during the compressional inversion phase and at the same time the overhang formed in the NE (Coniacian-Campanian). Compare this Fig. with sand-box model published by Koyi (1998, fig. 11 ). After Baldschuhn et al. (1998).

tectonic structuration will overly undisturbed and flat-lying Middle Buntsandstein (Herrmann et al., 1967). In southern Lower Saxony several of these socalled "Bruchfelder" are known.

If the primary thickness of the Permian salt is reduced, like in the western part of the LSB, the Zechstein salt wedges in the Upper Buntsandstein level may become a lubricant for sub-horizontal thrust planes. We are confronted here with three structural levels, separated by detachment planes, one being the basement beneath the Zechstein salt, one is formed by the Lower and Middle Buntsandstein and the third develops above the Upper Buntsandstein detachment horizon (Fig. 14).

The existence of salt wedges (Baldschuhn et al., 1998) is a strong argument against the assumption of excessive wrenching or horizontal movements along the main faults bordering the inversion structures. The salt wedges often start to develop from these main faults. Some of the salt wedges have been investigated in potassium mines and in none of these examples considerable deviations of salt-internal fold axis from the general B direction have been reported (Bornemann, 1979). This should be expected in case major horizontal movements had taken place along the fault from which the salt wedges originate during inversion.

In inverted basins salt obviously plays a more passive than active role. The salt structures become pas- sively deformed or the salt acts as a lubricant on thrusts. Nevertheless, salt has a strong influence on the morphology of the inversion structures. Where salt is absent, for instance in the Osning inversion, the reverse faults dip rather steeply and can be traced directly down into the basement (Baldschuhn \& Kockel, 1999; Fig. 15), whereas at the northern margin of the LSB (Figs 4, 8, $13 \& 14$ ) the thrusts are sub-horizontal and root in the Upper Buntsandstein or in the Zechstein levels (see also Nalpas, 1996). It appears difficult to appoint these thrusts in the overburden to a specific fault in the basement.

\section{The amount of movements during inversion}

400-600 meters of vertical uplift are estimated for the inverted Prignitz and Grimmen basins. The inversion of the Broad Fourteens Basin is 2 to $2,5 \mathrm{~km}$, Van Wijhe (1987), that of the Central Netherlands Basin according to NITG (1998) between 1,5 and $2 \mathrm{~km}$. In the centre of the LSB individual blocks are uplifted 8 $\mathrm{km}$ or more (Baldschuhn \& Kockel, 1999). The present day difference in height of the Zechstein base north of and on top of the Harz Mountains amounts to $4 \mathrm{~km}$; the real uplift probably was much more (see Fig. 16). The maximum magnitude of inversion in the Mid-Polish trough is estimated at about $2-2,5 \mathrm{~km}$ (Dadlez et al., 1997).

Horizontal displacement by now is not well investigated. It is assumed, that in the LSB the total amount of shortening in the basement is about $8 \mathrm{~km}$, but this figure is not based on balanced back-stripping.

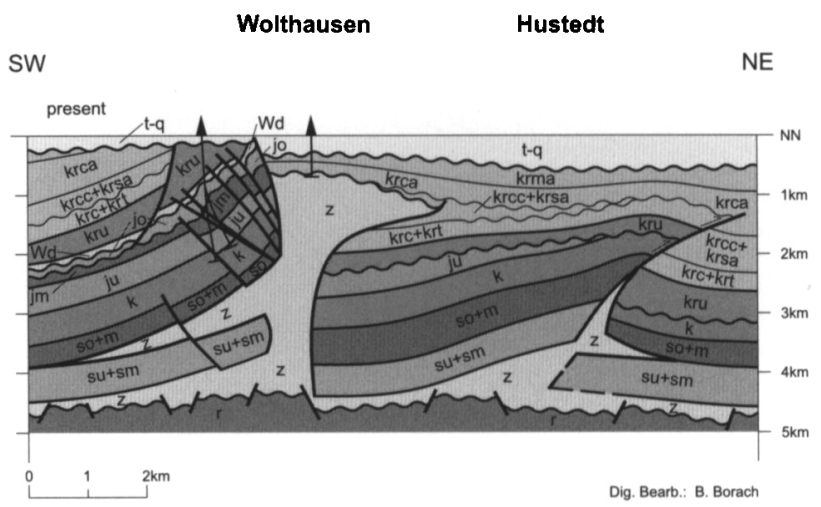

Fig. 13. Wolthausen salt structure (eastern LSB). The structure straddles the Aller lineament. The diapiric phase was reached in Late Jurassic-Early Cretaceous times (secondary rim syncline SW of the structure). During inversion salt was pressed out from the diapir to form a salt wedge to the SW into the Upper Buntsandstein salt level and a large overhang (possible submarine salt glacier in the Santonian sea). The salt structure rose further during Campanian and Maastrichtian (Baldschuhn et al., 1998). 


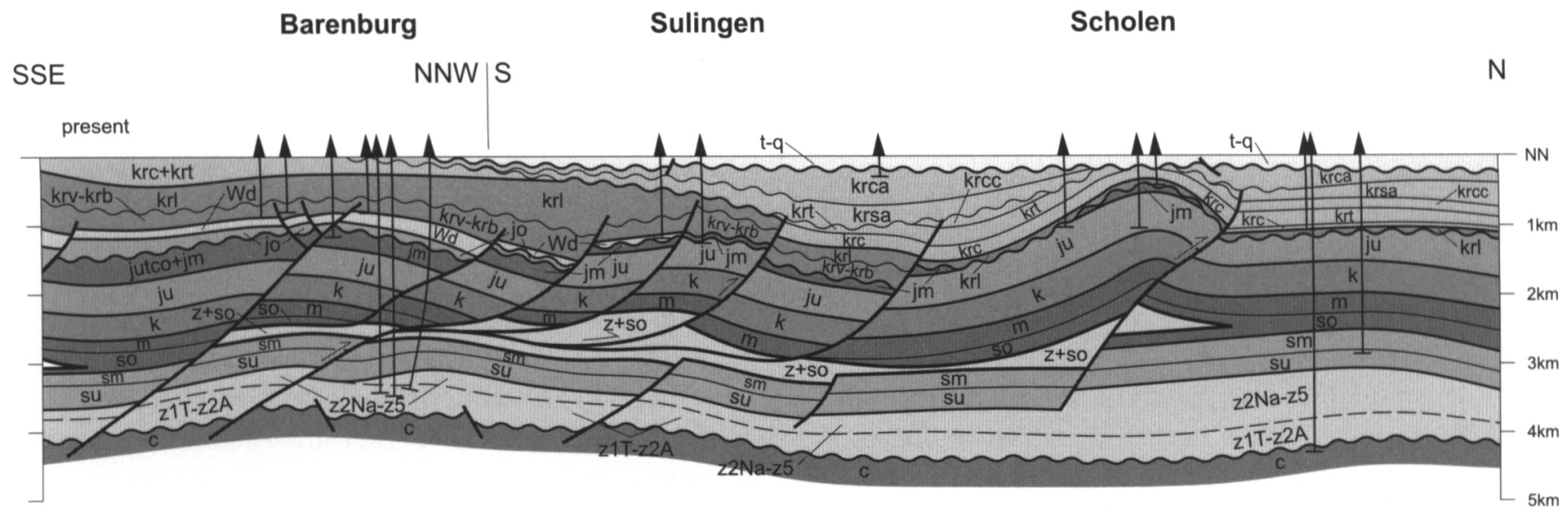

$0 \quad 1 \quad 2 \mathrm{~km}$

Dig. Bearb.: B. Borach

Fig 14. Barenburg, Sulingen, Scholen (western LSB). Inversion structures at the northern boundary of the LSB. Note the structural decollement in the Zechstein layer and in the Upper Buntsandstein salt level. The thrust plane is lubricated by Zechstein and Triassic salt (Baldschuhn et al., 1998).

\section{OSNING - ÜBERSCHIEBUNG}

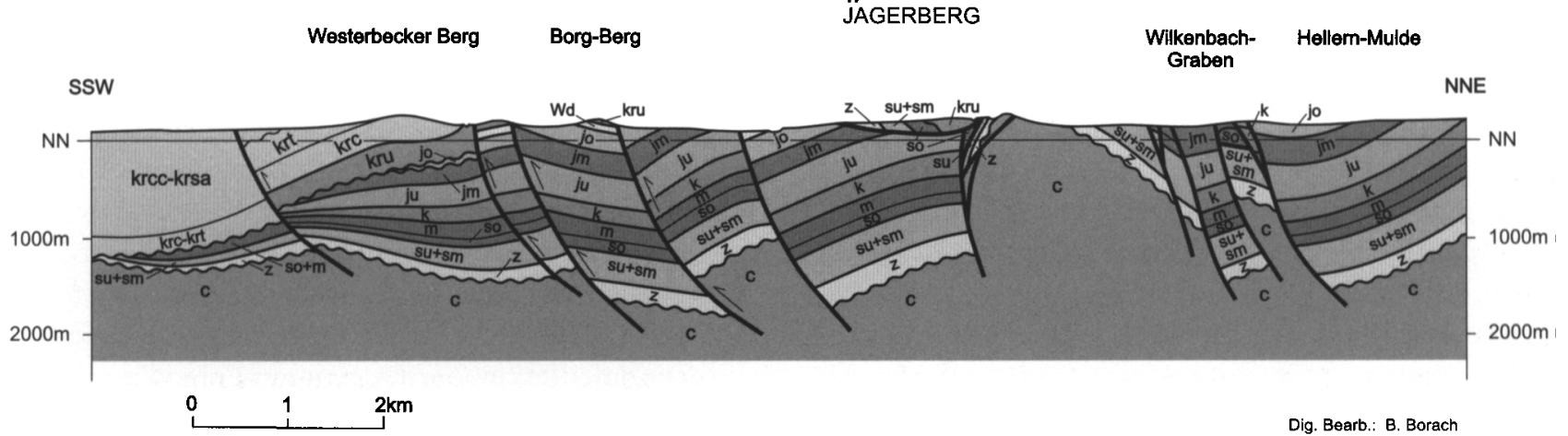

Fig. 15. Osning-Lineament - Nordwestfalen-Lippe-Schwelle (western LSB). Inverted southern margin of the LSB. No Zechstein salt is involved, the listric "phaeno-normal" faults root directly in the pre-Permian basement. Note the "subsequent marginal trough" filled with 1000 m of Coniacian and Santonian sediments south of the most southern thrust (Baldschuhn \& Kockel, 1998).
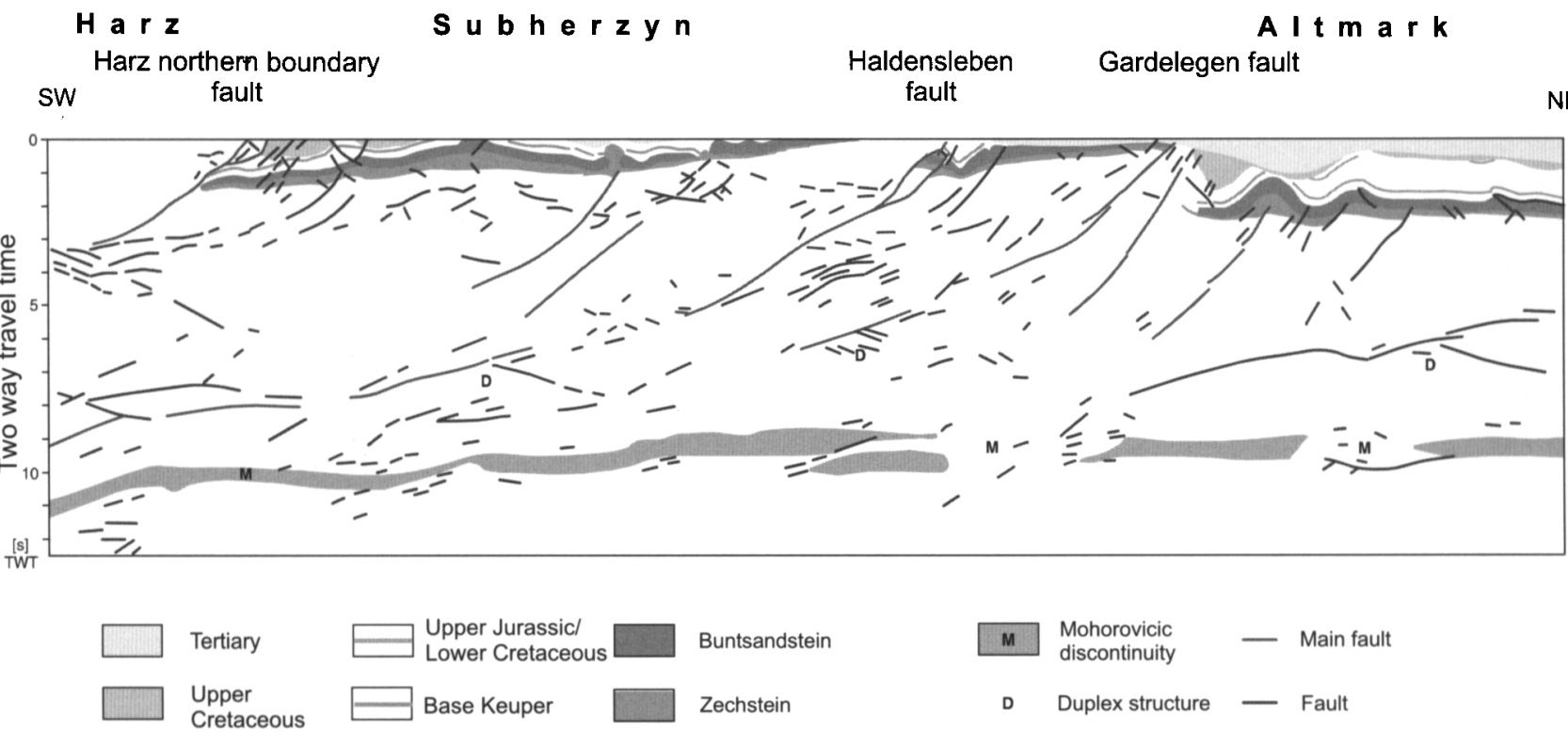

Fig. 16. Geological interpretation of a line drawing of the DEKORP section "Basin 96". Three inverted blocks, the Harz in the SW, the SubHercynian-Flechtingen block in the centre (limited by the Haldensleben fault) and the Calvörde block, limited by the Gardelegen fault are thrusted towards the NE along listric "thrusts" (reflectors) which root in the deeper crust. The MOHO is intensely blocked underneath (after Best \& Zirngast, 1998). 


\section{Features in the crust and mantle beneath the in- verted basins}

A seismic line with long registration times (Basin 96) was acquired running from the Harz Mountains to the north-east. It crosses the northern boundary fault of the Harz and shows several fault blocks north of the Harz (DEKORP Basin research group, 1999; Best \& Zirngast, 1998). Each fault block is inverted and thrusted towards the NE along SW-dipping listric fault planes. These fault planes root in the middle and lower crust, where duplex structures are developed (Fig. 16). In this section the Palaeozoic Harz block is thrusted $4 \mathrm{~km}$ or more onto the Sub-Hercynian basin. These thrust planes have moved during the Late Cretaceous inversion. The MOHO is strongly displaced and subsides from $9 \mathrm{~s}$ in the NE down to 11 s beneath the Harz.

There has been an attempt to map the depth of the $\mathrm{MOHO}$ in deep reflections seismic sections only (Hoffmann et al., 1997). The results are not very satisfying due to the lack of well-processed seismic sections with long registration time especially in West Germany. Inverted areas like the LSB or the Glückstadt graben in Schleswig-Holstein are characterised by MOHO highs; the Prignitz inversion on the other hand, is a MOHO low.

The inverted LSB is further characterised by a generally higher temperature gradient (50-55 degrees/1000 m; Hänel \& Staroste, 1988), if the sedimentary cover is still rather complete and no Triassic or older rocks come to the surface. For the Mid-Polish trough see Karnkowski (1999, fig. 45).

Very rarely in the European inverted basins the inversion phase is accompanied by plutonic intrusions in the centre of the basin. There exist intrusions in the centre of the LSB and they are characterised by magnetic and gravity as well as coalification anomalies (Koch et al., 1997) and strong hydrothermal activity. The emplacement time of these intrusions is not quite clear (later than Aptian, earlier than Campanian). The existence of these intrusions and their connection with inversion has been debated recently by Brink (2002) and Petmecky et al. (1999) but geophysical and geological evidence is still very strongly in favour for their existence.

\section{Discussion of theories to inversion}

There is a long and not yet ended discussion of the reasons of inversion (Ziegler, 1987a,b; Baldschuhn et al., 1991; Buchanan \& Buchanan, 1995; Dadlez et al., 1995; Ziegler et al., 1995; 1998; Vejbaek \& Andersen, 2001; Dadlez, 2001). The discussion concentrates on the question how it is possible that an intra-plate region of limited extension (graben, basin) subsides over a long period in an dilatational stress field and then suddenly, during a rather short time in a compressional or transpressional stress field becomes uplifted, its sediment fill becomes squeezed out and the former normal boundary faults become transformed into reverse faults and thrusts.

Several theoretical explanation of inversion processes have been offered, the best known and widely accepted one is the theory of P.A. Ziegler (Ziegler, 1987a,b; Ziegler et al., 1995): dilatation during the Jurassic and Early Cretaceous in northern Europe was steered by the gradual opening of the Atlantic. The compressional phase and crustal shortening on the contrary, was caused by the continent-continent collision of the African with the Eurasian plate at the northern margin of the Alps and Carpathians. The differences in inversion time for the different basins in central and western Europe are due to the different times of collision in the Carpathians in the east (Late Cretaceous) and in the Swiss and French Alps (Tertiary) in the west.

Whittaker (1985) saw the driving forces of inversion of the southern English basins in the reactivation of the Variscan thrust front beneath these basins. This is obviously not true for the Irish-Celtic Sea sector of the front (Dyment et al., 1990) and cannot explain inversion neither in Germany nor in Poland nor in the Netherlands. Late Cretaceous inversion structures straddling the Variscan front are known (Darfeld inversion on the Münsterland block; Gerling et al., 1999) but are exceptions.

Recently Vejbaek \& Andersen (2001) concluded that the inversion of the Danish part of the Central Graben resulted from a NNE-SSW-compression or transpression caused by ridge-push forces transmitted from sea-floor spreading south of the Charlie-Gibbs fracture zone, particularly from the Goban Spur SW of Ireland, acting in conjunction with Alpine orogenic stresses.

In order to find a comprehensive theory of inversion of the Central and Western European inverted sedimentary basins it seems necessary to collect more and more reliable data and informations on various topics in all the mentioned basins and in the Alpine realm as: timing of the inversion act, timing of the Alpine compressional pulses, geometry and orientation of the inverted basins or individual inversion structures, the mode of stress transfer over long distances, structure of the MOHO, present day and palaeo-temperature field, nature and intrusion time of the intrusive bodies beneath the basins, orientation of the stress field during the dilatational and compres- 
Table 2. Timing of the development of some German and adjacent inverted basins.

(Symbols see Table 1 and Fig. 2).

\begin{tabular}{|c|c|c|c|c|c|}
\hline Basin & rifting phase & $\begin{array}{l}\text { ruptual inversion } \\
\text { phase }\end{array}$ & $\begin{array}{l}\text { late updoming } \\
\text { phase }\end{array}$ & $\begin{array}{l}\text { tensional } \\
\text { reactivation phase }\end{array}$ & according to \\
\hline Lower Saxony Basin & ju - krp & $\mathrm{krcc}-\mathrm{krca}$ & - krmao & tpao-tpl & Baldschuhn et al., 1991 \\
\hline Prignitz Basin, Altmark & ju? - krp? & $\mathrm{krcc}-\mathrm{krca}$ & - krma & tpao - q? & unpublished \\
\hline Lusatian Block & $?-$ jo? & krtu - krca? & $?$ & $?$ & Voigt, 1997 \\
\hline Glückstadt Graben & ro $-\mathrm{k}, \mathrm{ju}$ & tpao-tmi & & & unpublished \\
\hline Mid Polish Trough & $\mathrm{z}-\mathrm{kru}$ & $\mathrm{krcc}-\mathrm{tpa}$ & - tol & & $\begin{array}{c}\text { Dadlez, } 2001 \\
\text { Lesczynski \& Dadlez, } 1999\end{array}$ \\
\hline West Netherlands Basin & sm - kru & krce - krmau & tpao - teo & tolo - q & Gras \& Geluk, 1998 \\
\hline Landshut-Neuötting High & ? j, kru? & $\mathrm{krcc}-\mathrm{krca}$ & - teoo/tol & tol, tmi & Bachmann et al., 1987 \\
\hline
\end{tabular}

sional phases, nature and origin of the marginal troughs.

\section{The time of inversion}

The timing of different phases of inversion of some of the Central European inverted basins is given in Table 2.

The main collision of the African plate with the Middle Penninian ridge and thus the disappearance of the Penninian ocean in the Alps took place in the
Austro-Alpine (Hauterivian to Barremian), the Austrian (Albian and Cenomanian) and in the Mediterranean phase (Turonian; Table 3). The Sub-Hercynian phase, (Ilsede and Wernigerode phase), the main inversion time in Central Europe, has been observed only on the consolidated eastern Alpine nappes but not in the Rheno-Danubian and Carpathian Magura ocean north of it. The Laramide phase at the beginning of the Tertiary, often described as another pulse of inversion, was not felt in the Alps at all. In northern Europe the Laramide unconformity is not the result

Table 3. Comparison of tectonic events in the Eastern Alps and in the LSB. Modified after Tollmann (1986). For more recent data see Trautwein et al. (2001). Heavy shading $=$ compressional stress field, light shading $=$ dilatational stress field.

Eastern Alps (from TOLLMANN, 1986)

\begin{tabular}{|c|c|c|c|c|c|c|}
\hline $\begin{array}{l}\text { orogenic } \\
\text { Phase }\end{array}$ & age & $\mathrm{Ma}$ & important events & age & $\mathrm{Ma}$ & events \\
\hline $\begin{array}{l}\text { latest alpine } \\
\text { cycles }\end{array}$ & $\begin{array}{c}\text { Pliocene, } \\
\text { Pannon- } \\
\text { ian,Sarmatian }\end{array}$ & & $\begin{array}{l}\text { disconformities, tilting of the alpine } \\
\text { forland towards the } \mathrm{E}\end{array}$ & & & tilting of mega-blocks \\
\hline Moldavian & $\begin{array}{c}\text { Sarmatian / } \\
\text { Badenian }\end{array}$ & 14 & non-sequencies in the Badenian & Miocene & 5,3 & \multirow{5}{*}{$\begin{array}{c}\text { dilatational and transtensional } \\
\text { movements at } \\
\text { several basement } \\
\text { block boundaries } \\
\text { of low intensity }\end{array}$} \\
\hline Sturian & intra-Miocene & 17 & last Flysch nappe movements & \multirow[b]{4}{*}{ U. Palaeocene } & \multirow[b]{4}{*}{61} & \\
\hline Savian & $\begin{array}{l}\text { L. Miocene - } \\
\text { U. Oligocene }\end{array}$ & 23,8 & $\begin{array}{c}\text { Flysch nappes, gliding in } \\
\text { Molasse trough }\end{array}$ & & & \\
\hline Helvetian & U/M. Oligocene & 27 & no record in Eastern Alps & & & \\
\hline Pyrenean & U. Eocene & 40 & $\begin{array}{l}\text { beginning of thrust movements in the } \\
\text { Flysch and Helvetian zones, post- } \\
\text { Gosauan thrusts in the Ostalpine }\end{array}$ & & & \\
\hline Laramide & $\begin{array}{l}\text { Palaeogene - } \\
\text { Maastrichtian }\end{array}$ & 65 & $\begin{array}{l}\text { local gaps in Gosau basin, in the } \\
\text { Eastern Alps of minor importance }\end{array}$ & $\begin{array}{c}\text { Maastrichtian } \\
/ \\
\text { Palaeocene }\end{array}$ & 65 & $\begin{array}{l}\text { several sea-level low-stands, } \\
\text { uplift and } \\
\text { erosion of inversion structures }\end{array}$ \\
\hline Ressen & $\begin{array}{c}\mathrm{U} / \mathrm{L} \\
\text { Campanian }\end{array}$ & 77,3 & $\begin{array}{l}\text { uplift of Central Zone, unconformities } \\
\text { in Gosau basin }\end{array}$ & Campanian & 77,3 & 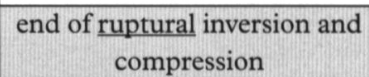 \\
\hline Wernigerode & $\begin{array}{l}\text { Campanian / } \\
\text { Santonian }\end{array}$ & 83,5 & moderate movements & $\begin{array}{l}\text { Santonian } \\
\text { to }\end{array}$ & $\begin{array}{c}83,5 \\
-\end{array}$ & $\begin{array}{c}\text { inversion in LSB and on } \\
\text { Pompeckj block, compression, }\end{array}$ \\
\hline Ilsede & $\mathrm{U} / \mathrm{M}$ Santonian & 84,3 & no record in Eastern Alps & Coniacian & 89 & transpression, thrusting \\
\hline Mediterranean & U.Turonian & 89 & $\begin{array}{c}\text { main nappe formation in the } \\
\text { Calcareous Alps, Gosau unconformity }\end{array}$ & & & \\
\hline Austrian & $\begin{array}{l}\text { Cenomanian / } \\
\text { Albian }\end{array}$ & 98,9 & continued nappe gliding, thrust of & & & \\
\hline Austroalpine & $\begin{array}{l}\text { Barrèmian / } \\
\text { Hauterivian }\end{array}$ & 127 & $\begin{array}{l}\text { start of nappe gliding in the } \\
\text { Central Zone }\end{array}$ & $\begin{array}{l}\text { Aptian - } \\
\text { Valanginian }\end{array}$ & $\begin{array}{r}112 \\
-137\end{array}$ & $\begin{array}{l}\text { transtensional and dilatational } \\
\text { rifting in the LSB }\end{array}$ \\
\hline
\end{tabular}


of a tectonic pulse but that of a couple of sea-level movements (Vinken, 1988). The continent-continent collision in the Alps and Carpathians and with it the closing of the Rheno-Danubian and Magura ocean took place in the Pyrenean phase in the Late Eocene/Early Oligocene and continued in the Savian and Sturian phases in the Miocene (for modern dating see Trautwein et al., 2001). During the Eocene to Miocene we observe feeble inversion of the Glückstadt Graben in Germany, late uplift in the Mid-Polish Trough and during the Miocene in the West Netherland Basin but none in the LSB or Prignitz/Altmark Basin.

The exact dating of tectonic movements - ruptural deformation or uplift - of inversion structures is essential and has not been done with the necessary care in many areas. In large areas marked by Ziegler et al. (1995; Figs. 12-13) to have suffered Tertiary compressional deformation (Franconia, Thuringia, Lusatia, southern part of the LSB) sediments younger than Late Cretaceous are entirely missing. The today apparent morphological differentiation of the Central German Middle mountains by the great fault zones like the Frankonian line, the Osning or the Harz northern boundary fault is very probably the result of reactivation of Cretaceous inverted thrusts in a tensional stress field during the Pliocene and Early Pleistocene connected with differential block uplift (Meyer \& Stets, 1998, Garetsky et al., 2001). Other former thrusts, the movements on which can be dated by syn-sedimentary Palaeocene sediments, show clear signs of relaxation or delatation. All Tertiary movements along faults in North Germany have been closely investigated and dated by Brückner-Röhling et al., 2002.

It should also been stressed that in every case a clears distinction has to be made between erosion and transgression caused by tectonic pulses and those caused by regional sea-level changes. This, deplorably, has not always been done and then may lead to wrong conclusions.

\section{Orientation of the inverted basins in respect to the Alpine collision front}

In Northern Europe a number of inversion structures have a rather unfavourable strike direction in respect to the E-W-running Alpine or Carpathian front: the NNE-running inverted the Rønne graben and its southern prolongation, the Brunswick-Gifhorn fracture zone, the NNW-striking Egge inversion zone and the Dutch North Sea graben. It is difficult to understand how they inverted by Alpine collision. This point is also stressed by Vejbæk \& Andersen (2001) for the inverted Danish part of the Central North Sea graben. Some of these inversion structures cross each other at a nearly 90 degree angle, but became inverted simultaneously in Coniacian-Santonian times (the WNW-running Osning and the NNW-running Egge, Baldschuhn \& Kockel (1999) the WNW-running Aller lineament, the NNE-running BrunswickGifhorn zone and the NNE-running Emtinghausen lineament (Fig. 1) Rønne graben and Scandinavian border zone). Along these inverted fault zones no major strike-slip movements have been observed, which should be expressed by displacement of structures, displacement of pre-inversion palaeogeography or by meso-tectonic features along the exposed faults (Harz northern boundary fault, Thuringian faults; Biewald \& Franzke, 2000).

\section{Mode of stress transfer over long distances:}

The most intense inversion should occur near the Alpine front beneath the Bavarian or Austrian Molasse basin. There is some inversion on the SW German block (Carlé, 1955) and in Thuringia (Biewald \& Franzke, 2000), but it is very feeble. Only $600 \mathrm{~km}$ farther north we see shortening of the crust of several $\mathrm{km}$ and alpine-type thrusting of more than $8 \mathrm{~km}$ distance. This is not in accordance with the assumptions of Ziegler et al. (1995).

\section{Orientation and age of inversion structures near the Alpine and Carpathian front}

Southern German inversion structures like the Landshut-Neuötting high (Bachmann et al., 1987) and several more in Austria (Nachtmann \& Wagner, 1987) generally strike NW-SE and at their south-eastern end have been covered by the Alpine nappes. These inversion structures existed prior to the emplacement of the Flysch, Helvetic and Upper Eastern Alpine nappes and have nothing to do with them. The southeastern prolongation of the inverted Holy Cross mountains near Rzeszów and Przemysl in SE Poland, which is part of the Mid-Polish inverted trough also strikes obliquely beneath the W-E-running Carpathian front (Znosko, 1998).

\section{The occurrence of the magmatic bodies in the centre of the LSB}

It seems difficult to imagine how a collision event 600 $\mathrm{km}$ to the south may trigger magmatic activities in the LSB. These magmatic intrusions are assumed to be related with the inversion process (consider also Brink, 2001). 


\section{Pre-disposition of inversion structures as syn- forms}

Only the former synforms, basins, grabens and alike, are affected by inversion, never the platform areas between the synforms. There is a close relationship between the amount of early subsidence and later inversion-related uplift. The shallow Prignitz Basin was uplifted only 400 to $600 \mathrm{~m}$, the deepest parts of the LSB several thousands of meters.

\section{The origin of the subsequent marginal troughs contemporaneously with inversion}

The phenomenon of the formation of subsequent marginal troughs has often been neglected in literature but is an integrated part of the inversion process. The subsequent marginal troughs, filled with Upper Cretaceous or Tertiary sediments, which are characteristic not only for the individual inversion structures (Figs 4 \& 5) but also for entirely inverted basins as a whole. As an example may serve the "Vor-Osning" trough on the northern margin of the Münsterland block immediately south of the Osning lineament, which forms the southern boundary of the LSB. This trough contains up to $2500 \mathrm{~m}$ of Upper Cretaceous sediments, partly as olisthostromes, derived from the rising LSB (Fig. 15). Other examples of marginal troughs are shown in Fig. 5 (Donsdorfer Mulde) and Fig. 8 (marginal trough infront of the northern boundary of the inverted LSB). Similar troughs have been listed from several European inverted basins already by Voigt (1962a). Up to now there is no comprehensive theory, which would include and may explain all these features observed in connection with intra-cratonic inversion.

\section{What brings us closer to an understanding of in- version processes?}

Most of the inverted basins are very well explored and in the future many new geophysical or geological data - deep bore-holes, deep reflection seismic lines - cannot be expected. So we have to rely mainly on the old data, but still several fields of further research exist, which have been unsatisfactorily dealt with in many basins in the past:

- Better regional investigations of the present day and paleo-temperature field and heat flow, considering also geological and structural data and including apatite fisson track analyses.

- Reconstruction of present day and palaeo-stress field.

- Detailed and quantitative investigations of local and regional uplift during inversion (sonic log analysis and coalification studies).

- Detailed regional coalification and maturity studies.

- 2D- and 3D-modelling of balanced sections and entire basins to estimate the horizontal crustal shortening during inversion and for better understanding HC-genesis and migration.

- Regional seismic velocity studies, considering structural and palaeo-geographical data.

- Isotope geochemical and organic geochemical studies of oil and gas deposits as well as source-rock investigations in inverted basins.

- Better reconstruction of fluid movements.

- Better seismic mapping of MOHO depth and depth of top crystalline basement.

- Better back-stripping of gravity and magnetic maps.

A good example of such a multi-disciplinary approach to an inverted basin, is given by Karnkowski (1999). For other basins this integration of different methods of geophysics and structural geology, organic geochemistry and isotope geochemistry is still lacking or not sufficiently developed.

\section{The impact of inversion on the hydrocarbon po- tential of inverted basins}

Inversion is of great importance to hydrocarbon prospectivity. The principles of oil generation in an inverted basin like the LSB are as follows: In the course of Jurassic/Lower Cretaceous subsidence oil was generated from the Jurassic or Lower Cretaceous source rocks in the centre of the basin and filled old, existing traps. In the very centre of the basin source rocks became over-mature as a consequence of deep burial. In the marginal parts of the basin, nevertheless, the source rocks remained immature. During the inversion the central intrusions enforced this process of over-maturation. As a consequence of the restructuration by inversion the old structural traps are destroyed. The marginal parts of the former basin subside as parts of the marginal troughs and hydrocarbons which started then to generate here migrated into traps, newly formed by inversion. $90 \%$ of the oilfilled structural traps in the LSB west of the Weser River originated in Coniacian and Santonian times and the oil in them is younger than Santonian in age. In Tertiary times we observe a general tilting of the LSB to the north and additional source-rocks in marginal parts of the northern basin fringe entered the oil kitchen. East of the Glückstadt graben Jurassic source-rocks became mature only by deep burial beneath the Eocene-filled marginal trough.

It is clear that only a tiny fraction of the original hydrocarbon potential of such an inverted basin is saved 
and can be produced. It was calculated that only $6 \%$ of the entire potential in the LSB is left and can be produced (Binot et al., 1993, Kockel et al., 1994).

About $60 \%$ of the German gas deposits are situated in basement structures which have been affected by Late Cretaceous inversion, re-structuring and uplift. Some of these structures had been uplifted several thousands of meters and were completely reshaped. From modelling we know that the bulk of gas generated from the Westphalian source rock in Triassic and Early Jurassic times. It seems improbable that during inversion the Zechstein salt seal covering the gas-filled palaeo-traps could remain intact. It is more likely that all the old gas, generated in pre-Coniacian times, escaped during inversion. The source rocks also became uplifted and thus transported into cooler levels out of the gas kitchen and expulsion of gas came to a halt. The question remains how it is possible that gas filled these structures which formed only in post-Campanian times? Has the gas, now produced, generated after the inversion directly from the source rock? Or has the gas originated earlier during subsidence and had been trapped by adsorption to the coal or dissolved in the pore fluids and now, by diminished temperature and pressure conditions, is released to migrate into the post-Santonian traps? This latter process may explain the puzzling distribution of $\mathrm{C}$ and $\mathrm{O}$ isotope patterns in deposits with Carboniferous, Zechstein and Lower Triassic reservoirs (Lokhorst et al., 1998).

\section{Conclusions}

Although inverted basins and individual inversion structures have been well studied in many parts of Europe, basic questions to the driving mechanisms of the inversion process remain unsolved. The fundamental question is why a long-lasting tensional environment suddenly and for only a short period of time, changes into a compressional environment and after that back again into a tensional one. Also the process and timing of gas generation prior, during and after inversion is not well understood. More combined and interdisciplinary research - structural geology, geophysics, geothermics, geochemistry, isotope geochemistry and numeric modelling is required to approach this fundamental and for hydrocarbon prospectivity estimation important process of inversion.

\section{Acknowledgement}

It is gratefully acknowledged, that the Petroleum industry, operating in Germany and organised in the Wirtschaftsverband Erdgas- und Erdölgewinnung e.
V. (WEG) permitted the publication of the geological sections. The colleagues G. Best and M. Zirngast are thanked for their permission to publish their geological interpretation of the southern part of the "Basin 96" DEKORP seismic section. And last but not least M. Geluk, P.A. Ziegler and O.V. Vejbaek as reviewers are thanked for their encouraging suggestions to improve the manuscript.

\section{References}

Bachmann, G.H., Müller, M. \& Weggen, K., 1987. Evolution of the Molasse Basin (Germany, Switzerland). Tectonophysics 137: 77 -92 .

Baldschuhn, R., Best, G. \& Kockel, F., 1991. Inversion tectonics in the north-west German basin. In: Spencer, A.M. (Ed.) Generation, accumulation and production of Europe's hydrocarbons. Special Publication of the European Association of Petroleum Geoscientists 1, Oxford University press (Oxford): 149-159.

Baldschuhn, R., Frisch, U. \& Kockel, F., 1996. Geotektonischer Atlas von NW-Deutschland 1 : 300000 , part 1-17, Bundesanstalt für Geowissenschaften und Rohstoffe (Hannover): 14 structural contour maps, 4 sheets each, 2 subcrop maps, 4 sheets each, 7 plates with cross-sections.

Baldschuhn, R., Frisch, U. \& Kockel, F., 1998. Der Salzkeil, ein strukturelles Requisit der saxonischen Tektonik. Zeitschrift der deutschen geologischen Gesellschaft 149: 59-69.

Baldschuhn, R. \& Kockel, F., 1999. Das Osning-Lineament am Südrand des Niedersachsen-Beckens. Zeitschrift der deutschen geologischen Gesellschaft 150: 673-695.

Baldschuhn, R., Binot, F., Fleig, S., \& Kockel, F. (Eds), 2001. Geotektonischer Atlas von Nordwest-Deutschland und dem deutschen Nordsee-Sektor - Strukturen, Strukturentwicklung, Paläogeographie. Geologisches Jahrbuch A 153: 1-88, 3 CD ROM.

Best, G. \& Zirngast, M., 1998. Analyse der strukturgeologischen Entwicklung der Salzstruktur Oberes Allertal und ihrer Umgebung. Unpublished report BGR, Archive-No. 116 873: 1-108.

Biewald, W. \& Franzke, H.J., 2000. Zur Ausbildung der Eichenberg-Saalfelder Störungszone an der Bündelungsstrecke A71/ICE zwischen Behringen und Roda (TK 25 Blatt 5232 Stadtilm). Geowissenschaftliche Mitteilungen von Thüringen 8: 5-31.

Binot, F., Gerling, P., Hiltmann, W., Kockel, F. \& Wehner, H., 1993. The Petroleum System in the Lower Saxony Basin. In: Spencer. A.M. (Ed.), Generation, accumulation and production of Europe's hydrocarbons. Special publication. European Association of Petroleum Geoscientist 3, Springer (Berlin, Heidelberg): 121-139.

Boigk, H., 1968. Gedanken zur Entwicklung des Niedersächsischen Tektogens. Geologisches Jahrbuch 85: 861-900.

Bornemann, O., 1979. Das Gefügeinventar nordwestdeutscher Salzstrukturen in Abhängigkeit von ihrer halokinetischen Stellung. Unpublished PhD. thesis (Braunschweig): 1-119.

Brink, H.-J., 2002. Die Anomalien von Bramsche, wieder eine offene Frage? Erdöl, Erdgas, Kohle 118: 18 - 22.

Brückner-Röhling, S., Espig, M., Fischer, M., Fleig, S., Forsbach, H., Kockel, F., Krull, P., Stiewe, H. \& Wirth, H., 2002. Standsicherheitsnachweise Nachbetriebsphase: Seismische Gefährdung, Teil 1: Strukturgeologie. Unpublished report Bundesanstalt für Geowissenschaften und Rohstoffe (Hannover).

Buchanan, J.G. \& Buchanan, P.G. (Eds), 1995. Basin inversion. 
Geological Society special publication 88 . Geological Society of London (London): 1-596.

Burke, K., 1977. Aulacogens and continental break-up. Annual review of Earth and Planetary science 5: 371-396.

Carlé, W., 1955. Bau und Entwicklung der Südwestdeutschen Großscholle. Beihefte zum Geologischen Jahrbuch 16: 1-272.

Dadlez, R., 2001. Mid-Polish trough - geological cross sections 1 : 200000 . Explanatory note. Polish Geological Institute (Warszawa): 1-29.

Dadlez, R., Jozwiak, W. \& Mlynarski, S., 1997. Subsidence and inversion of the western part of the Polish Basin - data from seismic velocities. Geological Quarterly 41: 197-208.

Dadlez, R., Narkiewicz, M., Stephenson, R.A., Visser, M.T.M. \& Van Wees, D.-J., 1995. Tectonic evolution of the Mid-Polish trough: modelling implications and significance for central European geology. Tectonophysics 252: 179-195.

DEKORP-Basin Research Group, 1999. Deep crustal structur of the Northeast German basin: New DEKORP BASIN '96 deep profiling results. Geology 27:55-58.

Dyment, J., Sibuet, J.-C. \& Pinet, B., 1990. Deep structure in the Celtic Sea: a discussion on the formation of basins. Tectonophysics 173: 435-444.

Garetsky, R. G., Ludwig, O. A., Schwab, G. \& Stackebrandt, W. (Eds), 2001. Neogeodynamics of the Baltic Sea depression and adjacent areas. Results of IGCP project 346. Brandenburgische geowissenschaftliche Beiträge 8: 1-47.

Gerling, P., Kockel, F. \& Krull, P., 1999. Das KohlenwasserstoffPotential des Präwestfals im norddeutschen Becken - eine Synthese. DGMK Forschungsbericht 433. Deutsche Wissenschaftliche Gesellschaft für Erdöl, Erdgas und Kohle e.V. (Hamburg): 1-107.

Gradstein. F. M., Agterberg, F. P., Ogg, I. G., Hardenbol, J. \& Backstrom, S., 1999. On the Cretaceous time scale. Neues Jahrbuch für Geologie und Paläontologie, Abhandlungen 212: 314.

Gras, R. \& Geluk, M.C., 1998. Late Cretaceous-Early Tertiary sedimentation in the southern Netherlands. Geologie en Mijnbouw 77: 1-16.

Hänel, R. \& Staroste, E. (Eds), 1988. Atlas of geothermal resources in the European Community, Austria and Switzerland. Commission of the European Communities, Hannover: 1-74.

Herrmann, A., Hinze, C. \& Stein, V., 1967. Die halokinetische Deutung der Elfas-Überschiebung im südniedersächsischen Bergland. Geologisches Jahrbuch 84: 407-462.

Heybroek, P., 1974. Explanation to tectonic maps of the Netherlands. Geologie en Mijnbouw 53: 43-50.

Heybroek, P., 1975. On the structure of the Dutch part of the Central North Sea Graben. In: Woodland A. W. (ed.), Petroleum and continental shelf of northwest Europe. Applied Science Publisher (London): 339-351.

Hoffmann, N., Stiewe, H. \& Pasternak, G., 1997. Struktur und Genese der Mohorovicic-Diskontinuität (Moho) im Norddeutschen Becken - ein Ergebnis langzeitregistrierter Steilwinkel-Seismik. Zeitschrift für angewandte Geologie 42: 138148.

Hooper, R.J., Leng Siang Goh \& Dewey, F., 1995. The inversion history of the northeastern margin of the Broad Fourteens Basin. In: Buchanan, J. G. \& Buchanan, P. G. (Eds). Basin Inversion. Geological Society special publication 88 . Geological Society of London (London): 319-338.

Huyghe, P. \& Mugnier, J.-L., 1995. A comparison of inverted basins of Southern North Sea and inverted structures of the external Alps. In: Buchanan, J. G. \& Buchanan, P. G. (Eds). Basin Inversion. Geological Society special publication 88 Geological Society of London (London): 339-353.
Karnkowski, P.H., 1999. Origin and evolution of the Polish Rotliegend basin. Polish Geological Institute special papers 3: 193.

Koch, J., Kockel, F. \& Krull, P., 1997. Coalification at the base Zechstein and the Pre-Permian surface in northern Germany. Geologisches Jahrbuch D 103: 33-42.

Kockel, F., 1998. Salt problems in northwest Germany and the German North Sea sector. Journal of seismic exploration 7: 219235.

Kockel, F., Wehner, H. \& Gerling, P., 1994. Petroleum systems of the Lower Saxony Basin, Germany. In: Magoon, L.B. \& Dow, W.G. (Eds). The petroleum system - from source to trap. American Association of Petroleum Geoscientists, Memoirs 60: 573586.

Koyi, H., 1998. The shaping of salt diapirs. Journal of Structural Geology 20: 321-338.

Lesczynski, K. \& Dadlez, R., 1999. Subsidence and the problem of incipient inversion in the Mid-Polish trough based on thickness maps and Cretaceous lithofacies analysis - discussion. Przglad Geologiczny 47: 625-628.

Lokhorst, A., Adlam, K., Brugge, J.V.M., David, P., Diapari, L., Fermont, W.J.J., Geluk, M., Gerling, P., Heckers, J., Kockel, F., Kotarba, M., Laier, T., Lott, G.K., Milaczewski, E., Milaczewski, L., Nicholson, R.A., Von Platen, F. \& Pokorski, J., 1998. NW European Gas Atlas - Composition and Isotope Ratios of Natural Gases. CD ROM. NITG (Haarlem). ISBN: 90-72869-60-5

Meyer, W. \& Stets, J., 1998. Junge Tektonik im Rheinischen Schiefergebirge und ihre Quantifizierung. Zeitschrift der deutschen geologischen Gesellschaft 149:359-379.

Nachtmann, W. \& Wagner, L., 1987. Mesozoic and Early Tertiary evolution of the Alpine foreland in Upper Austria and Salzburg, Austria. Tectonophysics 137: 61-76.

Nalpas, T., 1996. Inversion des grabens du sud de la Mer du Nord - données de sub-surface et modelisation analogique. Mémoires de Géosciences (Rennes) 71:1-241.

Nalpas, T., Le Douaran, S., Brun, J.-P., Unternehr, P \& Richert, J.P., 1995. Inversion of the Broad Fourteens Basin (Offshore Netherlands), a small scale model investigation. Sedimentary Geology 95: 237-250.

NITG, 1998. Geological Atlas of the Subsurface of the Netherlands $1: 250$ 000, Map Sheet X, Almelo--Winterswijk. NITG (Haarlem): 15 maps.

Pavlov, A. P., 1887. Samarskaja Luka e zeiguli. Trudi geologiceskago komiteta 1887, II, 5: 1-63.

Petmecky, S., Meier, L., Reiser, H. \& Littke, R., 1999. High thermal maturity in the Lower Saxony Basin: intrusion or deep burial? Tectonophysics 304: 317-344.

Schatski, N.S., 1961. Vergleichende Tektonik alter Tafeln. Fortschritte der sowjetischen Geologie 4. Akademie-Verlag (Berlin): 7-220.

Schatski, N. S. \& Bogdanow, A.A., 1958. Grundzüge des tektonischen Baus der Sowietunion. Erläuterungen zur tektonischen Karte der UdSSR, $1: 5 \mathrm{Mio}$. Fortschritte der sowjetischen Geologie 1. Akademie-Verlag (Berlin): 1-84.

Schreiber, A., 1957. Tektonische Stockwerke im Bau des mittleren Emslandes. Zeitschrift der deutschen geologischen Gesellschaft 109: 169-184.

Stille, H., 1917. Injektivfaltung und damit zusammenhängende Erscheinungen. Geologische Rundschau 8: 89-142.

Stille, H., 1923-1925. Die saxonischen Brüche (Schlußwort zu den "Göttinger Beiträgen zur Saxonischen Tektonik" 1923-1925). Abhandlungen der preußischen geologischen Landesanstalt, Neue Folge 95: 149-207.

Stovba, S.M . \& Stephenson, R. A., 1999. The Donbas fold belt: its relationships with the un-inverted Donets segment of the 
Dniepr-Donets basin, Ukraine. Tectonophysics 313: 59-83.

Tollmann, A., 1986. Geologie von Österreich, Band. 3: 1-718.

Trautwein, B., Dunkl, I. \& Frisch, W., 2001. Accretionary history of the Rheno-Danubian flysch zone in the Eastern Alps - evidence from apatite fission-track geochronology. International Journal of Earth Sciences, Geologische Rundschau 90: 703-713.

Van Wijhe, D.H., 1987. The structural evolution of the Broad Fourteens Basin. In: Brooks, J. \& Glennie, K. (Eds). Petroleum geology of North West Europe. Graham \& Trotman (London): 315 323.

Vejbæk, O.V. \& Andersen, C., 2001. Cretaceous - Palaeogene inversion tectonics in the Danish Central graben. Abstracts of the 63rd EAGE Conference and techhnical exhibition0-29 (Amsterdam): 1-4.

Vinken, R., (ed.), 1988: The NW-European Tertiary Basin. Geologisches Jahrbuch A 100: 1-508.

Voigt, E., 1962a. Über Randtröge vor Schollenrändern und ihre Bedeutung im Gebiet der Mitteleuropäischen Senke und angrenzender Gebiete. Zeitschrift der deutschen geologischen Gesellschaft 114:378-418.

Voigt, E., 1962b: Frühdiagenetische Deformation der turonen Plänerkalke bei Halle/Westfalen als Folge einer Großgleitung unter besonderer Berücksichtigung des Phakoid-Problems. Mitteilungen des geologischen Staatsinstituts Hamburg 31: 146275.

Voigt, T., 1997: Beckeninversion am Nordostrand der Böhmischen Masse - neue Daten zur mesozoischen Entwicklung Mitteleuropas. In: Büchel, G. \& Lützner, H. (Eds): Regionale Geologie von Mitteleuropa. Schriftenreihe der deutschen geologischen Gesellschaft 2: 117-118.

Whittaker, A. (ed.), 1985. Atlas of onshore sedimentary basins in England and Wales. Blackie (Glasgow, London): 1-71.

Wolburg, J., 1954. Schwellen und Becken im Emsland-Tektogen mit einem paläogeographischen Abriß von Wealden und Unterkreide. Beihefte zum Geologischen Jahrbuch 13: 1-115.

Wong, Th.E., Van Doorn, Th.H.M. \& Schroot, B., 1989. "Late Jurassic" petroleum geology of the Dutch Central North Sea Graben. Geologische Rundschau 78: 319-336.

Yegorova, T.P., Stephenson, R.A., Kozlenko, V.G., Starostenko, V.I. \& Legostaeva, O.V., 1999. 3D gravity analysis of the DnieprDonets basin and Donbas foldbelt, Ukraine. Tectonophysics 313: 41-58.

Ziegler, P.A., 1987 a. Late Cretaceous and Cenozoic intra-plate compressional deformations in the Alpine forland - a geodynamic model. Tectonophysics 137:389-420.

Ziegler, P.A. (ed.), 1987 b. Compressional intra-plate deformations in the Alpine forland. Tectonophysics 137:1-420.

Ziegler, P.A., 1990. Geological Atlas of Western and Central Europe 2nd Edition. Shell Internationale Petroleum Mij. BV and Geological Society of London (London): 1-239.

Ziegler, P.A., Cloetingh, S. \& Van Wees, J.-D. 1995. Dynamics of intra-plate compressional deformation: the Alpine forland and other examples. Tectonophysics 252: 7-59.

Ziegler, P.A., Van Wees, J.-D. \& Cloetingh, S. 1998. Mechanical controls on collision-related compressional intraplate deformation. Tectonophysics 300: 103-129.

Znosko, J. (Ed.), 1998. Tectonic Atlas of Poland. Polish Geological Institute (Warszawa): 1 map in 4 sheets $1: 500000,8$ inset maps. 